\title{
A Administração de Material em Face da Reforma Administrativa
}

\author{
Oscar Victorino Moreira
}

$\mathrm{H}$ regulada pICAMENTE a administração de material começou a ser Em 1931, Código de Contabilidade Pública, isto em 1922. Comiss̃̃ , com a expedição do Decreto $\mathrm{n}^{\circ}$ 19.587, criando a Comissão Central de Compras do Govêrno Federal, foi tentada uma forma de organização, através da centralização das compras. incluindo erros devidos ao desconhecimento do assunto por parte do legislador. Cabia àquela Comissão - «adquirir todo o material para o serviço público federal». Determinada a aquisição de todo o material para o serviço público, não excluía qualquer órgão, lògicamente. Assim, estariam incluídas as compras em todo o território nacional e dos ministérios civis e militares. Não poderia funcionar, seja pela vastidão do território nacional, seja pela falta de condições operacionais, seja pela relutância em aceitar a centralização das compras por parte de diversos órgãos. Assim, a centralização começou limitada à cidade do Rio de Janeiro e não incluindo o Ministério da Guerra, sendo que o da Marinha só se manteve subordinado até julho de 1934. A Polícia Militar do Distrito Federal e o Corpo de Bombeiros da cidade não se subordinaram àquela tentativa de centralização das compras. Se a idéia era boa, foi totalmente prejudicada, anulando o esfôrço que teria sido feito em tal sentido.

2. Em 1940, transforma-se aquela Comissão no Departamento Federal de Compras, por fôrça do Decreto-lei $\mathrm{n}^{9} 2.206$, em nova e promissora tentativa da centralização, mas deixando de ser extensiva a todo o serviço público, pois limitada ao serviço público civil, sendo que já diversos órgãos haviam sido transferidos para outras jurisdições. A nova lei previa a instalação de agências nos Estados, a fim de dar o âmbito nacional, só tendo sido criada uma em São Paulo, sempre funcionando precàriamente, principalmente pelo desinterêsse da administração. Quanto ao abastecimento por estoque do próprio órgão centralizador, houve uma experiência enquanto estava em sua direção um nome 
que devemos reverenciar, o do Dr. Fernando Martins Pereira e Souza. Mudada a direção, nunca mais houve interêsse, e entraves criados, como a incompetência e a má fé de direções produziram os piores resultados, o que exigiria uma apuração dos fatos ocorridos para serem aplicadas penalidades a quem foi culpado por desídia ou coisa pior, como por acobertar procedimentos lesivos aos cofres públicos. Seria, aqui, o momento de perguntarmos se foram tomadas as contas de todos os responsáveis e que lhes aconteceu. Sôbre êste assunto ninguém se atreve a falar por envolver fatos graves, responsabilidades claras e pessoas de alta posição, desfrutando de amparo politico. Se o momento é o da moralização da administração pública, seria oportuno revelar o ocorrido e aplicar aos responsáveis de alto coturno as sanções, já que estas não devem restringir-se só aos pequenos, aos desafortunados.

3. Com a criação do DASP, surgiu o órgão superior na administração de Material, ou seja, a sua Divisão de Material, a qual encetou trabalhos que a honraram. Em pouco tempo de sua existência, ela iniciou a padronização do material, elaborou perto de trinta Catálogos de Material, dinamizou a administração e envidou meios para o melhor entrosamento dessa administração, sendo criado o Conselho de Administração de Material. O que ainda possuímos de apreciável nesse setor, é anterior a 1945. pois nesse ano foi baixado o Decreto-lei $\mathrm{n}^{\circ}$ 8.323-A, que retirou do DASP sua Divisão de Material e o Conselho que funcionava junto a êle e os transferiu para o Departamento Federal de Compras, sem atribuiçôes e sem verificar as peculiaridades, do que resultou na estagnação completa de ambos os órgãos. Basta dizer que nem o cargo de Diretor da Divisão fôra transferido. só aparecendo pela forma mais curiosa possivel através da Lei $n^{\circ}$ 488, de 15 de novembro de 1948 (Lei de aumento de vencimentos do pessoal!)

4. O «exercício» do cargo em comissão dessa Divisão é uma das sinecuras procuradas, pois no exato sentido da palavra, trata-se de um cargo que não tem atribuições, já que o próprio órgão não as possui. De 1948 até hoje, vem o cargo sendo provido e um de seus ocupantes, por ter nêle permanecido por mais de 10 anos consecutivos, logrou o amparo da Lei $n^{\circ} 1.741$, sendo agregado como um prêmio pela sua dedicação e constância em tal período...

5. Quando advertimos a direção do órgão no início do Govêrno passado sôbre êsse fato, notamos que seria de seu agrado a permanência da situação, tanto assim que o cargo foi provido, e assinale-se que isso ocorreu após a Revolução de 31 de março. 
6. Perdendo o DASP sua Divisão de Material e transferido - Conselho para o D.F.C., não houve mais quem zelasse pela boa administração nesse setor. Há que ser notada a decisão do Govêrno Jânio Quadros que determinou caber ao D.F.C. a realização dos processos de compras de material para órgãos ou ministérios que não se incluiam na centralização. Só o processo, mas o exame de características, como o contrôle de recebimento, a qualidade e a quantidade não estavam sujeitas ao órgão que processara. Isso e nada é a mesma coisa. De modo algum evitou o que aquêle Govêrno teria desejado, antes excluiu a responsabilidade dos que seriam julgados faltosos e contra os quais teria aquela medida sido tomada. 7. Agora, vem o Decreto-lei $n^{2} 200$, que instituiu a Reforma
Administrativa e toma medidas neste setor, as quais desejamos comentar, seja pelo interêsse que sempre demonstramos por êste campo de atividade, seja pelo fato de nos ter cabido a honra de presidir o Grupo de Trabalho para a Reorganização do Sistema de Material, quando o Ministro Amaral Peixoto estava encarregado dos estudos para a Reforma Administrativa. É de ser dito que nosso trabalho mereceu a aprovação do Govêrno de então e em mensagem foi remetido ao Congresso, tendo sido apreciado pela Câmara dos Deputados e ai aprovado, sendo relator o
ilustre Deputado Marechal Juarez do Nascimento Fernandes
Távora.

8. Nenhum dos membros de nosso Grupo de Trabalho, como o que apresentamos foi ouvido ou lido, seja pelos organizadores da Reforma Administrativa, seja pelos que, no Congresso ou Não desejamos, tomaram parte da feitura do nôvo documento. êle deveria ser dizer que nosso trabalho fôsse perfeito, que só Juarez Távora aprovado, mas a figura insuspeita do Marechal aceitou nosso constitui ótima indicação, ótimo Juiz, e foi quem Decreto-lei no trabalho, elogiando-o. A forma preconizada no parece a mais feliz setor da administração de material, não nos autoridades que zela e isto iremos expor, fazendo um apêlo às sentido de verificarem os males e pontos merecedores de reparo.

9. Antes de qualquer outro comentário técnico, é nosso desejo colocar em relêvo um aspeto que consideramos, acima de tudo, moral, isto pelo conhecimento que possuímos e que os de boa formação moral, interessados na moralidade da coisa pública, também conhecem.

10. Concorrência pública. - Sua forma de realização, prescrita no Código de Contabilidade e seus entraves, assim como a participação de órgãos que a apreciavam por um ponto-devista que não seria o da eficiência da administração pública, mas de estreito sentido de fiscalização, não é uma forma ideal para 
as compras de material, mas, em todo o caso, constituía um meio para tentar evitar males maiores. Se ela era má, em sua forma, um melhor processo deveria ser encontrado para a mesma, mas sempre com o objetivo de salvaguardar os cofres públicos. $\mathrm{O}$ lado moral, a defesa do patrimônio constituem sempre objetivos da lei. Com o advento da Revolução, esforços têm sido feitos para a moralização da coisa pública, assim como no sentido da defesa do erário. Pois bem, apresentamos, em seguida, a evolução dos limites a partir dos quais é exigida a concorrência pública para a compra de material, como medida acauteladora da fortuna pública.

1922 - Pèo Código de Contabilidade Pública - (Vamos apresentar em cruzeiros novos, para facilidade de

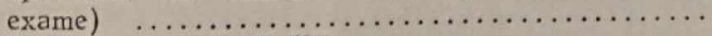

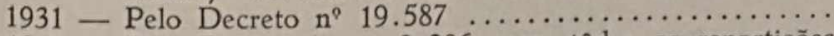

1940 - Pelo Decreto-lei n².206, para tôdas as repartiçŏes Para o Departamento Federal de Compras, órgão centralizador das compras de material .............

$\mathrm{NCr} \$$

1967 - Pelo Decreto-lei $\mathrm{n}^{\circ} 200$, para tôdas as repartiçōes,
DFC, autarquias, etc., o equivalente a 10.000 salá-
rios minimos (os maiores vigentes e, no momento,
iguais a NCr\$ 105,00$) \ldots \ldots \ldots \ldots \ldots \ldots \ldots \ldots \ldots \ldots \ldots \ldots \ldots \ldots$

1967 - Pelo Decreto-lei $\mathrm{n}^{0} 200$, para tôdas as repartições,
DFC, autarquias, etc.., o equivalente a 10.000 salá-
rios minimos (os maiores vigentes e, no momento,
iguais a NCr\$ 105,00$) \ldots \ldots \ldots \ldots \ldots \ldots \ldots \ldots \ldots \ldots \ldots \ldots \ldots$

1967 - Pelo Decreto-lei $\mathrm{n}^{0} 200$, para tôdas as repartições,
DFC, autarquias, etc.., o equivalente a 10.000 salá-
rios minimos (os maiores vigentes e, no momento,
iguais a NCr\$ 105,00$) \ldots \ldots \ldots \ldots \ldots \ldots \ldots \ldots \ldots \ldots \ldots \ldots \ldots$

1967 - Pelo Decreto-lei $\mathrm{n}^{0} 200$, para tôdas as repartições,
DFC, autarquias, etc.., o equivalente a 10.000 salá-
rios minimos (os maiores vigentes e, no momento,
iguais a NCr\$ 105,00$) \ldots \ldots \ldots \ldots \ldots \ldots \ldots \ldots \ldots \ldots \ldots \ldots \ldots$

A progressão foi a seguinte:

De 1922 a 1931, em nove anos ............

De 1931 a 1940, ou nove anos ..............

De 1940 a 1967, ou vinte e sete anos ........

10 vêzes

10 vêzes

2.100 vêzes

A ser seguida a progressão anterior, deveríamos ter, em vez do constante da nova Lei, apenas - NCr\$500.000,00. No projeto apresentado pelo Grupo de Trabalho a que já nos referimos, o limite mencionado era de NCr\$ 400.000,00. Devemos, ainda, verificar que, possivelmente no próximo ano, tenhamos um nôvo salário-minimo, dadas as condições econômicas atuais e o que sentimos e não deverão ser os salários majorados em base menor de $30 \%$, ao nosso ver. Assim, o limite estabelecido pelo Decreto-lei $\mathrm{n}^{\circ} 200$, passará a $\mathrm{NCr} \$ 1.365 .000,00$ !

11. Haverá mais concorrências públicas para compra de material? Justamente o contrário, dada a desmesurada elevação do limite de sua obrigatoriedade. E é de ser notado que o limite para o caso de obras, foi elevado para 15.000 salários-mínimos. Sejamos práticos. Na construção de um edifício de grande porte, dentro das normas habituais, não se contrata tôda a obra com uma só emprêsa, mesmo porque, pela especialização, uma se encarrega das fundações, outra da alvenaria, outra da estrutura, outra de esquadrias etc. Assim, os contratos serão naturalmente subdivididos. Nesse caso, o estaqueamento e fundações atingirão a 15.000 salários-mínimos (atualmente $\mathrm{NCr} \$ 1.575 .000,00$ )? Não nos parece provável. Os demais contratos atingirão àquela soma? 
Mas o edifício custará, talvez, somando-se tôdas as parcelas componentes, aproximadamente $\mathrm{NCr} \$ 18.000 .000,00$ ! Embora tão elevada importância, não serão necessárias concorrências públicas. Um edifício se decompõe, pelo menos, nas seguintes parcelas ou partes:

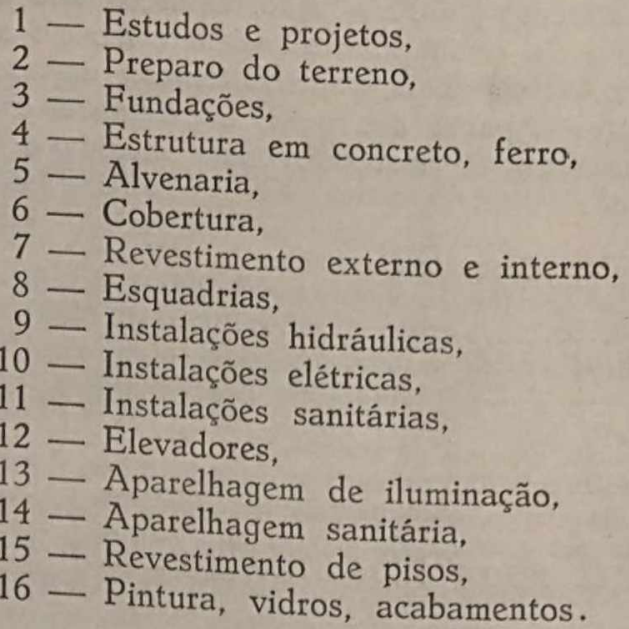

Ora, nenhuma dessas dezesseis parcelas isoladamente atirfge ao limite a partir do qual é exigida a concorrência pública, mas seus montantes adicionais podem ultrapassar a casa dos ......... $\mathrm{NCr} \$ 18.000 .000,00$. Verificamos que o legislador não examinou êste aspeto e facultou um procedimento legal que, talvez, não seja o protetor do erário público, pela dispensa de formalidades, pela não exigência de contratos formais com garantias etc.

12. O acima exposto se refere a obras, e na administração de material que se passa? Qual a compra de uma só vez que atinge a casa dos $\mathrm{NCr} \$ 1.050 .000,00$ ? Ademais, pode tal compra ser parcelada, isto é, feita em duas, três ou quatro etapas e, assim, para cada uma delas atingir o limite, precisaria ser daquele vulto e a sua totalidade atingiria a perto de .......... NCr\$ 4.200.000,00, sem a obrigatoriedade de concorrências públicas.

13. Este é um aspeto que reputamos importante, pois diz respeito à proteção dos cofres públicos: Podemos, entretanto, seja laborando em êrro, quando pensamos que a concorrência lei no 200 dos dinheiros públicos. O Art. 126, do Decretoção. Já o Art. essa modalidade 127, definindo a concorrência pública, diz que rer, dado o vulto licitação é a que deve a Administração recorlicitante o vulto e quando se admite a participação de qualquer 
a «Tomada de preços» $\left(\S 3^{\circ}\right)$ é a modalidade de licitação entre interessados prèviamente registrados, observada a necessária habilitação. Neste caso se trata de «círculo fechado», quando se organizam grupos que dominam setores, o que é de todos amplamente conhecido. Basta verificar a diferença na publicidade entre essas duas modalidades de licitação para sabermos de suas conseqüências (Art. 129, itens I e II). Notemos as palavras contidas no $\S 3^{\circ}$, do Art. 127; por elas, não é aberta oportunidade a qualquer, mesmo capacitado, a participar da licitação. Para que seja essa oportunidade aberta, só no caso da concorrência, quando será comprovada a sua qualificação ( $\$ 2^{\circ}$ ). Ademais, a repartição não está obrigada a aceitar outros licitantes, podendo limitar-se sòmente aos inscritos. Será essa a melhor forma de moralizar a coisa pública? E onde ficará o princípio democrático da igualdade de oportunidades a todos que se encontrem em condições de competir? Aliás, por que falar em democracia, em se tratando de administração de material?...

14. Democràticamente, a 17 de janeiro de 1944 , pelo Decreto-lei $\mathrm{n}^{\circ}$ 6.204, foi instituido o «Registro de Fornecedores do Govêrno Federal», facultativo e que assegurava ao inscrito, prova perante quaisquer repartições públicas, autarquias ou entidades paraestatais, das condições gerais de capacidade prescritas em lei e para habilitação em concorrências ou coletas de preços (Art. 2\%). Isso foi desconhecido pelo Decreto-lei $n^{\circ} 200$. O Art. 128 dessa Lei determina que - as repartições - façam seus registros particulares, não havendo menção ao registro instituído pelo citado Decreto-lei $n^{\circ}$ 6.204. Este foi revogado ou ocorreu, apenas, desconhecimento de seu texto? O de 1944 era amplo e assegurava amplas garantias, enquanto o atual é restritivo. Onde a melhoria? Não a encontramos.

15. Tomada de preços. - Trata-se do nôvo nome da antiga concorrência administrativa. O Art. 127 declara que haverá três tipos de licitação e esta é o segundo. Já nos referimos ao conteúdo do $\S 3^{\circ}$. No inciso II, do Art. 129, é dito que - «no caso de tomada de preços, mediante afixação de edital, com antecedência mínima de quinze dias, em local acessível aos interessados e comunicação às entidades de classe, que os representem» - mas combinado com o disposto no $\S 3^{\circ}$ do Art. 127, far-se-á a tomada de preços. Êsse tipo de licitação alcança um teto de dez mil vêzes o maior salário-mínimo, ou os ........ NCr\$ $1.050 .000,00$, pois daí para mais já é a concorrência (pública). A afixação do edital, embora em local acessivel aos interessados, fica restrita àqueles que privam com a repartição, os quotidianos, os «iniciados》. A maior divulgação das licitações (parágrafo único do Art. 129) fica a cargo do desejo da repartição em fazê-la. O meio existe, mas se considerarmos que todos são honestos, nem precisariamos de leis. A realidade bem conhe- 
cida não nos leva a acreditar que só haja honestos. A lei deve resguardar o erário, embora admitamos a honestidade, ela tem a obrigação de ser previdente.

16. A supressão de formalidades na Tomada de Preços, embora para aquisições previstas de valor que pode atingir a elevadissimo montante, parece-nos má para os cofres públicos. Um dos meios de defesa dos cofres públicos é a lavratura de contrato bilateral, mas êste só é obrigatório no caso de concorrência (pública), já que nos "demais casos de licitação é facultativo, segundo o prescrito no Art. 134, inciso I. Mesmo que feito o contrato, a prestação de garantia (caução contratual), é facultativa (Art. 135), mesmo simples garantia bancária, securatória ou fidejussória. Se o contratante inadimplir o contrato, de que modo serão protegidos os cofres públicos quando não foi exigida qualquer caução? A dispensa de garantia é admissível, mas dentro de certos limites de crédito ou confiança, mas para as importâncias previstas nessa Lei, entendemos que desprotegem os cofres públicos, pelo uso do critério ou arbítrio pessoal.

17. O Art. 141 prevê o exame da habilitação do licitante por uma comissão de três membros, para indicarem sua capacidade e a permissão para licitar. Deixa a Lei de fazer qualquer, determinação sôbre a qualificação dêsses membros. Poderã̃o ser refere a qualiógrafos, escriturários etc. Como o artigo. se ou exe a qualquer tipo de licitação para fornecimento de material ou execução de obras, será interessante verificar que os escriturários irão opinar sôbre a capacidade técnica de emprêsas que irão construir uma ponte, um edifício ou outra obra de vulto e de requisitos técnicos que engenheiros necessitam de conhecimentos especializados para opinarem; mas é a lei.

18. Quanto à questão da afixação de editais em locais acessiveis, há que ser notado que o Decreto-lei $n^{2} 2.206$ determina que os editais devem ser afixados em local de fácil acesso. Êsse local é no oitavo pavimento do Palácio da Fazenda e assim atendida a Lei. Os interessados, dispondo de lanternas elétricas, além de boa capacidade visual, poderão ver. Será isso o que a Lei deseja? O que o comprador deveria fazer para a obtenção de melhores preços e melhor material, não é isso. Se tal procedimento fôsse o que propiciasse bons resultados, as emprêsas privadas o usariam. O comprador oficial, limitado pela lei e não possuindo o propósito de agir bem para com o dinheiro público, limita-se ao cumprimento fiel da lei, embora não alcançando os melhores resultados. A emprêsa privada visa o lucro e selı agente se vê na contigência de agir de modo a proporcionar aquêle lucro, usando as formas capazes para tanto. No serviço público há outra mentalidade. 
19. Convite. - Êste têrmo substituiu a coleta de preços, a qual havia sido pèssimamente regulada pelo Art. 33, do Decreto $\mathrm{n}^{9}$ 5.873, que dizia - «serem feitas por qualquer processo comercial». Redação insuficiente que necessitava reparo profundo. Como foi o reparo feito? Diz o $\S 4^{\circ}$, do Art. 127, o seguinte:

«Convite é a modalidade de licitação entre interessados no ramo pertinente ao objeto da licitação, em número mínimo de três, escolhidos pela unidade administrativa, registrados ou não, e convocados por escrito com antecedência mínima de 3 (três) dias úteis».

Não abre essa disposição a oportunidade para algum possível licitante que tenha «ouvido dizer» que ela se realizará para participar da mesma, isto porque não foi escolhido pela unidade administrativa. Não se trata de mera suposição, pois conhecemos caso em que certo fornecedor se apresentando com uma proposta, aliás a de menor preço, não venceu a licitação efetivamente, já que foi anulada aquela coleta de preços e realizada outra, da qual êle não tivera conhecimento e, por isso, ficou de fora, recaindo a compra em outro fornecedor merecedor da estima especial da unidade...

20. A indicação dos - três - convites a licitantes, não representa qualquer defesa dos cofres públicos. Certo fornecedor, da intimidade da unidade administrativa, pode ser o portador dos três convites que, por mero acaso, serão entregues a amigos seus para o fim especial de apresentarem propostas cobrindo a sua. Estaremos dizendo algum absurdo ou será isso assunto amplamente conhecido dos que trabalham no ramo da administração de material? Êsse convite, como regulado, evitará deslizes? Continuará a mesma situação anterior que desejamos enfrentar quando o Grupo de Trabalho, com tanto empenho, se dedicou à tarefa de redigir o anteprojeto de Reorganização do Sistema de Material.

21. Se nos preocupamos em falar sôbre êsse ponto, necessário se faz examinarmos a quanto irá o teto para os convites. $\mathrm{O} \S 5^{\circ}$, do Art. 127 determina em até cem vêzes o valor do maior salário-mínimo, ou, no momento, $N C r \$ 10.500,00$, que na linguagem antiga é muito mais expressiva - dez milhões e quinhentos mil cruzeiros. - Tal limite, convenhamos, é bastante alto para tão poucas precauções. A maioria das compras realizadas pelo Departamento Federal de Compras, como órgão centralizador fica abaixo dêsse limite. Haverá comentário a ser feito diante do fato? Mas, o aspeto moral que vimos expondo. ainda apresenta uma surprêsa. Três são as modalidades de licitação, afirmadas no Art. 127; todavia há outra que não sendo nominada, chamemo-la de - NADA. 
22. Nada. - Diz a alinea i), do Art. 126:

«nas compras ou execução de obras e serviços de pequeno vulto, entendidos como tal os que envolverem importância inferior a cinco vêzes, no caso de compras, e serviços e a cinqüienta vêzes, no caso de obras, o valor do maior salário-mínimo mensal.»

Traduzindo, no momento, os valôres acima, na base de $\mathrm{NCr} \$ 105,00$, do maior salário-minimo, temos, respectivamente: - NCr\$ 525,00 e NCr\$ 5.250,00. Até êsses limites nem aquela insuficiente exigência do citado artigo 33 , do Decreto 5.873 , do - processo comercial - existirá. Pràticamente, até $\operatorname{NCr} \$ 525,00$ das podem ser o dôbro, o triplo, ou ainda mais, por parcelamento das compras, será dinheiro na mão, recibo (real?) e a coisa comprada. Permitam-me, ante o fato, usar uma linguagem fora da técnica e entender que isso na gíria é um verdadeiro «show» de moralidade, ó que delícia de «show»! Antes, ao tempo da lei que foi mudada e se o foi é porque não atendia à moralidade administrativa, o Tribunal de Contas exigia comprovação hábil de gastos de NCr\$1,00 e aplicava glosas como considerava em alcance o portador do adiantamento que antecipasse dinheiro de seu bôlso à Administração; hoje, quinhentos, mil ou mil e quinhentos cruzeiros novos não assustam ninguém, prescindem de maiores contrôles, aconteceu o milagre: desapareceram os desonestós!...

\section{ASPETO TÉCNICO-ADMINISTRATIVO}

23. Por uma questão de técnica legislativa, a matéria contida nos parágrafos $1^{\circ}, 2^{\circ}$ e $3^{\circ}$, do Art. 126, deveria ser tratada" após a constante do Art. 135. Primeiramente a lei deve disciplinar e determinar o que deva ser feito e depois abrir as exceçôes. como a dispensa de licitação que está colocada antes de ser definida a licitação.

24. O Art. 126 determina estrita observância do princípio da licitação e seus três parágrafos só cuidam da dispensa dessa licitação. Os casos mencionados no $\S 2 \%$, reúnem disposiçôes encontradas no Art. 38, do Decreto-lei n' 2.206, de 1940 e Art. 49, da Lei $\mathrm{n}^{\circ} 830$ (Orgânica do Tribunal de Contas). Ra alinea b), há a previsão de autorização do Presidente da República; nos demais casos fica na alçada do dirigente da repartição. Antes havia os casos dependentes da autorização do Ministro da Fazenda (alineas b), c) e e), do Art. 38, do Decreto-lei $n^{\circ} 2.206$, de 1940), hoje desaparecida.

25. Quanto às modalidades de licitação já nos referimos $e$ estão contidas nos Arts. 127 e 128 . Ocorre, porém, que o $\S 2^{\circ}$, do citado Art. 128 , está assim redigido: 
«as unidades administrativas que incidentalmente não disponham de registro cadastral poderão socorrer-se do de outra.» (Grifamos)

Ora, o cumprimento das leis depende de seu entendimento, de sua precisão, de sua clareza e quando emprega têrmos inusitados, o comentarista deve ter o cuidado de verificá-los para não incorrer em êrro de apreciação. Por isso, encontrada a palavra grifada no texto transcrito, recorremos ao socorro do dicionário e fomos a Laudelino Freire para nossa garantia e aí lemos, o seguinte:

«Incidentalmente, adv. De incidental mais mente.

De modo incidental.

Incidental, adj. Relativo a incidente ou que tenha caráter de incidente.

Incidente, adj. Lat. incidens, entis. Que incide; que sobrevém, acessório, superveniente. Diz-se da proposição acessória na frase, ligada a uma das palavras da proposição principal pelo respectivo conjuntivo para comentar ou explicar. - Fato que sobrevém no decurso de um fato principal. Dificuldade que alguém suscita numa questão.»

Evidentemente aquêle advérbio não deveria ser empregado e sim, outro usual - «eventualmente» - pois a circunstância deveria ser eventual e jamais um - incidente. Notemos que essa Lei deve ser cumprida por todo o serviço público, seja na administração direta, seja na paraestatal, por muitos níveis funcionais, portanto de clareza meridiana e insofismável, como altamente inteligivel. Ocorreu isso?

26. A seguir, vêm disposições quanto à publicidade das licitações. No caso das concorrências foi fixado o prazo da publicação em órgão oficial e na imprensa diária do edital, em 30 dias. Parece a quem não estiver atento que tal prazo será suficiente para moralidade e defesa dos cofres públicos. No vulto das concorrências há aparelhagem ou construçốes que exigem estudos e pesquisas que demandam muito mais tempo. Suponhamos a construção de uma grande ponte sôbre um rio, quando será necessário conhecer a vazão dêsse rio durante um período de dois anos, suas variações, sondagens do terreno etc. Os 30 dias bastarão, ou nesse prazo só os «iniciados», os que já tiveram tempo bastante para seus estudos entrarão na licitação para vencer, deixando à margem outros possíveis competidores que não tiveram oportunidade de adivinhar? $\mathrm{O}$ prazo dos 30 dias será exíguo em certos casos e excessivo noutros. Permite o deslize, permite os «entendimentos», e outros procedimentos que deveriam ser evitados. O legislador não se mostrou conhe- 
cedor dos meandros da administração e não foram previstas as medidas convenientes e eficazes.

27. O Art. 130 especifica condições do edital, peça fundamental na licitação. O item VIII se refere à natureza da garantia para execução de fornecimento ou realização de serviços ou obras, «quando exigida». $\hat{E}$ o caso da dispensa de tal garantia, mesmo ante o vulto da despesa.

28. O princípio jurídico de que é permissivel fazer-se o que a lei não impedir chega a ser desconhecido de alguns. Diz o parágrafo único do artigo 129 que a administração poderá utilizar outros meios de informação ao seu alcance para maior divulgação das licitações. A utilização dos outros meios de informação não é proibida por lei, logo, permissivel e não será pela inclusão dêsse parágrafo que a administração poderá utili-
zá-los.

29. No Art. 129, inciso IV, encontramos uma disposição perigosa, conforme o caso. O Código de Contabilidade, a despeito dos erros que contém, foi previdente e estipulou que as têrmos do edital conter uma forma de inteira submissão aos administrador estabesprezar essa exigência de permitir que o das propostas, pstabeleça condições próprias para o julgamento a certo proponenterá facultar meios para servir exclusivamente legislador não pode que se enquadre na forma preconizada. os fatos e tomar a ser ingênuo, precisa saber como se processam 30. descrição sucinciso $\mathrm{V}$, dêsse artigo é dito que o edital conterá forma sucinta e vice precisa da licitação. A precisão afastará a não será o certo, mas a A descrição da licitação, como dito, do objeto da lescrição, no sentido de especificação,

31. O paragrafo dosta.

justifique $\mathrm{p}$ parágrafo do Art. 133 exige que o administrador menor. O Código a escolha de preço que não tenha sido o cabe, de direito, a de Contabilidade dizia que a «concorrência que seja a diferença.» de 1931, foi mais intel O Decreto n 19.587 , de 14 de janeiro que - para definteligente neste particular, quando determinava menor ônus para significa o menor os cofres públicos. Nem sempre o menor preço quando a exper onus. O Decreto lei $n^{\circ} 200$, volveu ao Código, perdendo se a

de se evoluir.

Neste caso Art. 134 se refere aos contratos de modo precário. dispositivos haverá remissão ao Código, sendo vários de seus obrigações decorráveis em face da atual legislação? Nas 
hábeis, entre êles o empenho. O empenho prévio, obrigação indispensável para a unidade administrativa, muito mais que para o contratante, não pode ficar igualado aos outros documentos, porque êle é o defensor do erário, do principio constitucional de que não poderá fazer-se despesa além dos créditos orçamentários. O significado verdadeiro do empenho é muito maior e o antigo Código disso dava boas contas, enquanto é hoje tratado como simples formalidade. Pena é que a administração não sinta isso, não verifique que deveria dar o valor que êle deve ter. Vale apontar o que se passava na administração. Esta realizava uma licitação, o proponente apresentava a melhor proposta, a êle adjudicado o fornecimento. O fornecedor cumpria sua parte corretamente; a repartição recebia o material, entrando em sua posse, empregava-o e entregava ao fornecedor seus documentos em condições de ser processado o pagamento da coisa comprada. Indo ao Tribunal de Contas para registro prévio da despesa, êste discordava da classificação orçamentária da despesa e recusava aquêle registro, do qual decorreria o pagamento. Com a recusa, não era pago aquilo que o Estado adquiriu e do que entrou em sua posse, utilizando-o! E tal acontecia a despeito da definição de empenho encontrada no Código. - «O empenho prévio de despesa é o ato emanado da autoridade, que cria para a administração uma obrigação de pagamento.» Que espécie de obrigação era essa que não valia, dada uma simples interpretação de classificação orçamentária? O Estado não deu ao empenho a fôrça que deveria ter e não correspondia efetivamente a uma obrigação.

33. O Estado para ter fôrça moral deve dar o exemplo. Se adquiriu alguma coisa $e$ os fatos se processaram legalmente, questiúnculas internas não podem suprimir obrigações. $\mathrm{Na}$ órbita da administração privada tal não pode acontecer. Se a emprêsa comprou alguma coisa, a recebeu, entrou em sua posse e a utilizou, jamais poderá furtar-se ao pagamento devido. Não fôra essa impossibilidade e não haveria certas falências. O serviço público, por atitudes como a comentada, se desmoraliza, o que a lei deve impedir, de qualquer modo; é necessário que o Estado se imponha pela correção de seus atos, não valendo as alegações da impropriedade de classificação orçamentária ou outras. A responsabilidade é do Estado; se seu agente errou, a correção e as conseqüências têm de ser de âmbito interno e não podem atingir a quem cumpriu honestamente sua parte. Por outro lado, o fornecedor sabendo dos percalços, onera preços. pratica atos menos lícitos e é acusado de tais atitudes, mas é levado, até certo ponto, a assim agir. A atitude moral do Estado será sua melhor defesa, como o meio para impor para com êle idêntico tratamento. A ação moral tem fôrça para obter reciprocidade. 
34. Já vimos o bastante para verificarmos a necessidade de uma revisão da recente Lei, no que concerne à administração de Material. Resta, ainda, fazermos um comentário sôbre um ponto que julgamos importante e se encontra na criação do Departamento de Serviços Gerais no Ministério da Fazenda (Arts. 192 a 197).

35. A Lei criou um órgão que se ocupará de três atividades de naturezas bem diversas. Quanto ao patrimônio imobiliário, existia o Serviço do Patrimônio da União, onde as funções hoje previstas já eram lá exercidas, incluindo cadastro, aforamento etc.; a outra conhecida função se refere à administração de edifícios e instalações que estavam afetas à Divisão de Edifícios Públicos do DASP. No DASP, como órgão da Presidência da República, fora do âmbito Ministerial, a função supervisora e fiscalizadora tinha determinado sentido; passando, agora, a ser exercida por um Ministério, verificamos a ocorrência de um ministério se imiscuir na administração dos demais. Temos o receio de atritos e rivalidades, o que não ocorria quando a capacidade era atribuída a órgão não ministerial. Outra função atribuída ao órgão criado (D.S.G.M.F.) é a do abastecimento de material ao serviço público e parte da competência do DASP antes de sua mutilação em 1945, ou seja a parte normativa que êle possuia nesse campo. Quando foi expedido o Decreto-lei número 8.323-A, a 7 de dezembro de 1945 (por mera coincidência, traiçoeiro que, quatro anos antes, a América do Norte sofreu o dos e devitaque a Pearl Harbor) verificamos os malefícios ocorritamos neste à falta de conhecimento da matéria, como já comenadministração trabalho. Apreciaremos, agora, só o referente à

\section{«Quanto à Administração de Material:}

a) estudos de classificação, especificação e do catálogo de material de uso comum, em colaboração com os setores técnicos interessados, do serviço público e do setor privado, para aprovação do Govêrno;

b) realização das compras que o Govêrno julgue conveniente centralizar;

c) elaboração de normas de recuperação e redistribuição de material;

d) elaboração de normas de alienação de material considerado desnecessário.»

36. Pelo disposto na alínea a), verificamos a citação à preli-se do nome adotado pelo DASP para indicar um trabalho catálogos existemplificação, não sendo expressão comum, pois de Encargos» etc. Sem a expressa indicação do que seja o 
catálogo, fica o sentido no vago. A elaboração do Catálogo pelo DASP foi uma obra que mereceu elogios de todos os setores de atividade e de órgãos estrangeiros, sendo elaborado em colaboração com o Instituto Nacional de Tecnologia, com variados órgãos do serviço público e com entidades - setor privado incluindo-se a valiosa colaboração da Associação Brasileira de Normas Técnicas. Diz a Lei, todavia, que os trabalhos serão para aprovação do Govêrno. Govêrno, no caso, não podemos entender o Presidente da República, mas um órgão; qual? Deveria a Lei determinar, para validade, o órgão com essa capacidade, mas foi isso omitido.

37. A centralização de compras, como está dito, permitirá o que os mais influentes, os que possuem mais fôrça politica desejam, ou seja, não se sujeitarão a ela e não há obrigação legal para tanto, basta ter fôrça, o que fará desaparecer tal centralização. Por outro lado, para haver centralização real, a imposição legal da distribuição automática de créditos ao órgão centralizador é imprescindivel. A lei não fala nisso. Diz a disposição em foco que isso acontecerá quando o Govêrno julgue conveniente. Trata-se do mesmo caso, isto é, caberá ao Presidente da República ou um órgão será o juiz?

38. No inciso c) fala a lei em normas de recuperação e redistribuição de material. Sinto-me feliz em que o assunto seja lembrado, pois fui premiado em concurso com um trabalho sôbre essa matéria, mas a simples elaboração de normas fica muito aquém do preciso e não vejo como terá fôrça para funcionar. Quem irá dizer da necessidade de recuperar ou de redistribuir o material? Tratando-se de assunto vasto, os esclarecimentos que poderíamos prestar estão contidos na monografia editada pelo DASP intitulada - «Conservação e Recuperação de Material».

39. O inciso ainda contém a alínea d), que determina a elaboração de normas de alienação de material considerado desnecessário. Êsse assunto é decorrente do anterior e estamos na mesma situação comentada. Alienação é uma coisa: julgar o material desnecessário é bem diferente. É evidente a deficiência da lei ao tratar a administração de material, pois há outros assuntos importantes deixados à margem. O que desejamos é a eficiência do material adquirido, a obtenção de bons preços, uma forma rápida de abastecimento a par de uma forma que atraia os melhores fornecedores. Um segredo muito conhecido e que podemos revelar na arte de administrar bem o material é o seguinte: - Quem compra e paga bem e rápido, obtém melhores preços e melhor qualidade. Que foi feito nesse sentido nessa lei? Já tivemos oportunidade de dirigir um órgão de certa envergadura e quando assumimos o cargo, apenas uns três fornecedores eram os «donos», os que vendiam ao órgão, pois só êles 
gozavam das facilidades e sabiam quando receberiam seu dinheiro, o que elevava os preços fortemente. Poucos meses após, radicalmente mudada a politica administrativa, lançando mãos daquele segredo, a situação se transformou, caindo os preços em mais de quarenta por cento e melhorando as qualidades dos materiais adquiridos.

40. Pelo que compreendemos na criação do Departamento de Serviços Gerais, com três tipos bem diversos de incumbências, não houve melhoria para o serviço público e no que tange à administração de material, não podemos aplaudir. Não se trata de nossa qualificação profissional, pelo fato de havermos ingressado no quadro do DASP, em concurso, para exercer o cargo de Técnico de Administração, especializados em material, nem pelo fato de havermos dirigido órgãos onde se praticava a administração do material, mas pela condição de autor de diversos trabalhos premiados nessa matéria, e como professor dêsse ramo desde 1939, o que julgamos uma credencial bastante para criticarmos o assunto, não influindo o fato de havermos presidido o Grupo de Trabalho de Estudo da Reorganização do Sistema de Material, ao tempo em que o Ministro Amaral Peixoto estava à frente do Ministério Extraordinário para a Reforma Administrativa. O trabalho foi do Grupo, do qual me honro de ter pertencido, dado o alto gabarito de seus componentes. Já nos apresentamos, como vários daquele Grupo, o que bastará para indicar que não temos intuito de lograrmos novas posições, fazendo a crítica em benefício da administração pública, como um sentido de dever. Não entendemos, de modo algum, sermos o único dono da verdade, mas sentimos profundamente o fato de ter sido elaborada uma lei que poderia atender bem aos fins a que se destina e não encontramos razões que nos levem a antever
tal coisa.

41. Finalmente, fazemos um apêlo no sentido de que seja revista, ao menos a parte referente à administração de material e que se lhe dê os elementos de que carece para ser atuante, benéfica e moralizante da administração, o que será trabalho patriótico altamente elogiável. 